\title{
Grupo Acolhida Ambulatorial
}

\author{
Andrade, Paulo Antonio da Silva; Rodriguez, Lorgio Henrique Diaz; Souza, Jane \\ Lopes de
}

Instituto do Câncer do Estado de São Paulo - Icesp - paulo.andrade@icesp.org.br

Introdução: o Programa Nacional de Humanização da Assistência Hospitalar lançado em 2001 pelo Ministério da Saúde teve como objetivo "Valorizar a dimensão humana e subjetiva, presente em todo ato de assistência à saúde..." ao enfatizar a complexa dimensão da pessoa humana, o Ministério da Saúde resgata a noção de que o tratamento é, primordialmente, o modo pelo qual nos sentimos tratados, recebidos, orientados e, portanto, requer hospitalidade e um encontro solícito em que compareça o desvelo e a preocupação com o outro. Objetivo: Oferecer grupos de recepção e acolhimento aos novos pacientes e seus acompanhantes que diariamente nos procuram para iniciar seu tratamento oncológico e buscar minimizar medos, ansiedades e mitos a respeito do câncer e sua terapêutica, além de informar sobre o funcionamento do hospital. Método: Atualmente é composto por aproximadamente 60 funcionários da área assistencial: psicologia, nutrição, enfermagem, farmácia, assistência social e reabilitação. Os grupos são realizados de $2^{\underline{a}}$ a $6^{\underline{a}}$ feira, das 8 às $9 \mathrm{~h}$ e das $13 \mathrm{~h}$ às $14 \mathrm{~h}$ em nível ambulatorial. Após a medição de sinais realizada pela equipe de enfermagem, os novos pacientes são dirigidos a uma sala onde encontrão um profissional da assistência que apresenta os objetivos do encontro: que todos possam conhecer o lugar onde estão chegando, as pessoas que deles irão cuidar, assim como podem perguntar e tirar suas duvidas sobre as principais modalidades de combate ao câncer. a consulta medica só acontece depois do grupo. em seguida, pacientes e acompanhantes são convidados a se apresentarem brevemente da maneira que desejarem. um conjunto de slides especialmente preparados por cada uma das áreas envolvidas é utilizado como roteiro para apresentar sucintamente os principais tipos de tratamento oncológico disponíveis, recursos diagnósticos, direitos, serviços, profissionais e orientações gerais sobre como acessá-los. ao final, é entregue uma pasta contendo um folheto com mais algumas informações e telefones úteis aos pacientes. na sequencia todos são direcionados aos consultórios médicos. Resultado: o programa Grupo Acolhida Ambulatorial já recebeu desde o inicio, mais de 20.000 participantes, entre pacientes e acompanhantes e ao término de cada grupo, todos agradecem fortemente o acolhimento, demonstrando redução importante do medo e ansiedade inicial em relação ao tratamento e primeira consulta médica, assim como orientados sobre as rotinas do hospital. Conclusão: a atividade de acolhimento e recepção em grupo de novos pacientes tem demonstrado ser eficiente em valorizar o contato humano entre profissionais e usuários do nosso serviço hospitalar e adequar expectativas, reduzir medos e desfazer os mitos associados ao câncer e seu tratamento.

Andrade, Paulo Antonio da Silva; Rodriguez, Lorgio Henrique Diaz; Souza, Jane Lopes de. Grupo Acolhida Ambulatorial. In: Anais do Congresso Internacional de Humanidades \& Humanização em Saúde [= Blucher Medical Proceedings, num.2, vol.1]. São Paulo: Editora Blucher, 2014. ISSN 2357-7282 DOI 10.5151/medpro-cihhs-10739 